\title{
Introduction
}

\section{Antipoverty Measures \\ The Potential for Shaming and Dignity Building through Delivery Interactions}

\author{
Erika Gubrium and Sony Pellissery
}

\begin{abstract}
The special issue focuses on the impact of antipoverty measures-accounting for social and structural dimensions in the poverty experience and moving beyond an income-only focus - in five country cases: China, India, Norway, Uganda, and the United States. Particularly, we focus on the implications of shame in the delivery of antipoverty measures, as an individual and social phenomenon that relates to feelings of self-inadequacy, as well to a lack of dignity and recognition. We analyze delivery interactions through an analytic framework of rights, discretion and negotiation, as this enables us to parse out how policy delivery interactions presumed or enabled individual choice, ability, control, and voice. We suggest social citizenship can structure the relationships between welfare recipients and administrators. As a concept, it expands the objects of social rights beyond the materiality of human life (e.g., housing, pensions) to include intangible processual elements (e.g., dignity) in the construct of rights.
\end{abstract}

Keywords: antipoverty policy, dignity, policy implementation, policy practice, recognition, shame, social citizenship

This special issue focuses on the impact of antipoverty measures delivered in five widely varying country cases across the Global North and South. China, India, Norway, the United States, and Uganda represent opposite extremes-culturally, politically, and in type and level of social protection afforded to their most vulnerable residents. In China and India, the global impacts of economic crisis and modernization have been deeply felt because of enormous economic growth at a fast pace. These economies have witnessed radical changes in the past decade. The rise of the middle class and greater economic strength has been accompanied by a widening gap between the rich and the poor. Increased relative poverty has been especially marked in urban 
areas. Uganda's varying antipoverty approaches over the past twenty-five years have been touted as a best-case model in the developing world (Hickey 2011). Yet the country was and remains ranked among the poorest countries in the world, with poverty especially marked in rural areas and endemic corruption a key challenge (Bantebya Kyomuhendo 2014). Norway is a "social democratic welfare state" exhibiting the unique combined features of a high standard of living with a low level of inequality. Yet relative poverty is increasing and the income gap has grown in Norway, despite its healthy economy and generous welfare system. In contrast, in the "liberal welfare state" of the United States, a weak institutional structure and a highly decentralized welfare system have contributed to a context in which support for welfare institutions and welfare policy is limited (Larsen 2006). The United States has also seen a widening gap between the rich and the poor, accompanied by growing economic depression in recent years.

With relative poverty and socioeconomic inequality increasing in all of our research cases, poverty solutions-whether provided in a top-down manner by policymakers or more locally by social workers and antipoverty relief workers-must begin to account for social and structural dimensions in the poverty experience and move beyond an income-only focus. While these cases vary greatly in scope and structure, they are all contexts for the potential shaming and stigmatization of those in poverty. The articles in this special issue represent the culmination of a research project, "Poverty and Shame: Perspectives and Practices Concerning Anti-poverty Measures in a Global Context," funded by the Research Council of Norway. The project investigated service provision interactions between antipoverty measure providers and recipients in the five research cases. Our work is concentrated on the changing world of antipoverty measure provision internationally, cross-culturally, and comparatively. Our analysis focuses on how the elements of rights, discretion, and negotiation shape service provision interactions. The findings offer an empirical basis for identifying how shame may be reflected in provider discourses and for identifying the connections between these discourses and antipoverty measure implementation. This is a first step toward identifying how antipoverty measures may be "shameproofed," how they may help to promote dignity and individual agency.

Our focus on the personal and social impact of antipoverty policy is globally relevant in light of the United Nations (UN) Sustainable Development Goals. Replacing the UN Millennium Development Goals, the new goals aim to shape a social protection system capable of "ending poverty in all its forms everywhere" (UNSD 2017; emphasis added). Our shame-proofing objective gained explicit global salience in the 2013 resolution of the UN General Assembly on extreme poverty and in the 2012 International Labor Organization (ILO) Recommendation 202, with 185 countries agreeing to implement a social protection floor. Our research was cited directly by policymakers who called for the inclusion of Recommendation 202, the principle that all governments should respect the rights and dignity of those receiving 
assistance. The evidence provided here, however, suggests that policymakers and practitioners still have a long way to go in implementing this principle.

\section{Aims and Objectives}

While earlier scholarship recognizes the shame experienced by individuals living in poverty, little attention has been paid to the implications of shame in the delivery of antipoverty measures. Instead, stigma, or "shame bureaucratized" (Walker 2014: 49), has long been referenced when describing the experience of economic or social marginality and used to explain policy ineffectiveness (see Baumberg et al. 2012; Dovidio et al. 2000; Goffman 1963; Pinker 1971; Spicker 1984). While not referring specifically to "shame," several scholars have reported instances of stigmatization and shaming in the delivery of antipoverty services (Lipsky 1980; Narayan et al. 2000). Across vastly different country cases, our earlier findings supported the contention that attention to this dimension across the spectrum of professional practice could vastly enhance measure effectiveness, by promoting human dignity and fostering economic growth that was more socially sustainable. In this special issue, we focus on how shaming and dignity building are connected to the experiences and practices associated with the implementation and delivery of antipoverty measures. We define implementation as the translation of goals into operational rules and guidelines, the coordination of resources and personnel to achieve the intended goals, and the provision of services, programs and benefits attached to these goals.

Our methods for evaluating the impact of antipoverty measures are innovative. Research in Europe and North America assessing the impact of antipoverty measures has largely followed an economic focus. The work has evaluated "hard" outputs in terms of movement into employment (see Betcherman et al. 2004; Kluve 2006; Rønsen and Skarðhamar 2009) and "softer" outputs associated with basic quality of life (e.g., Malmberg-Heimonen and Vuori 2005; Schafft and Spjelkavik 2011). Rik van Berkel and colleagues have written on the norms and discourses shaping professional practices within the context of labor activation implementation (Borghi and van Berkel 2007; van Berkel and Valkenburg 2007), yet this work tends not to focus on professional practices at the level of everyday interaction and the impact of service delivery on those receiving antipoverty measures.

The empirical articles that follow begin to fill this scholarly gap. They draw from scholarship focused on the experience of the welfare system user (Caswell et al. 2011; Hall et al. 2003; Juhila and Abrams 2011; Olesen and Eskelinen 2011; Seltzer et al. 2001), as well as from scholarship focused on the everyday practices of a street level bureaucrat (Brodkin and Marston 2013; Gubrium et al. forthcoming; Hupe et al. 2015; Jewell 2007; Lipsky 1980). Experience and interaction are key: the rights of a measure recipient are theoretically determined by eligibility thresholds and benefit levels/offers, yet in practice, rights may be mitigated or increased according to the 
service delivery interaction (Chen 2015). An investigation as to how policies are delivered and experienced on the ground is crucial when gauging how rights, discretion, and negotiation play out in the implementation of antipoverty measures.

We conducted our studies across five "most different" country cases. In China, we looked at delivery of the national minimum income program. In India, we looked at midday meal service delivery. In Uganda, we looked at a cash transfer program for the elderly. In the United States, we looked at public housing. In Norway we looked at a labor activation program targeted to recipients of social assistance. In each case, we engaged with stakeholders via in-depth interviews with measure users and providers (street level bureaucrats, caseworkers, midlevel managers), and in most cases, we conducted observations of delivery interactions.

The articles that follow focus on how day-to-day understandings and practices produced via measure implementation may shape the poverty-shame-dignity nexus, as well as how politically and institutionally shaped contexts are mutually informed by and inform such understandings and practices. Each article attends to the following questions:

- What is happening to and understood by the recipient?

- What is intended by and understood by service provider?

- How is the service performed?

\section{Poverty, Shame, and Dignity}

Poverty is a concept that has been defined and measured in numerous ways. Broadly speaking, income level is used to describe poverty as "absolute" or "relative," yet the definitions of these categories have also been a matter of debate (see Sen 1983; Townsend 1979). Our working definition of poverty moves beyond a sole focus on income or the material (what someone earns or owns) to the multidimensional and relational. In addition to failing to have the necessary food, housing, and income to survive, the concept of poverty also speaks to whether individuals have the resources and capacities, the "capability," to function in acceptable ways according to the prevailing standards and resources of their local communities and broader societies (Lister 2004; Robeyns 2005; Sen 1999, 2005). Yet the freedom to function according to such standards is "shackled by poverty" (Lister 2004: 160). The UN Development Programme (UNDP) recognizes this lack of freedom to function as a violation of basic human rights (UNDP 2003).

Amartya Sen (1983) has argued that a key capability located at the "irreducible absolutist core" of poverty is the "ability to go about without shame." While poverty has a strong material dimension, it is also a "shameful and corrosive social relation" (Lister 2004: 7; emphasis added). It is thus crucial to consider what scholar Ruth 
Lister terms the "relational/symbolic" aspects of poverty when assessing the impact of measures aiming to reduce it.

What is shame, and what links it to the poverty experience? Scholars examining the individual, emotional impact of shame describe it as a combination of sadness/ disappointment, anger, and fear directed at the self (Turner and Maryanski 2013). Emotionally, shame represents a "dissolution of the self" (Scheff 2000: 96). One may feel guilt over what one has done, behavior that it is within one's control to change, thus connoting the idea of a "choice." In contrast, an individual feels shame about what one $i s$, about how one is perceived by one's peers and by society at large (see Figure 1). One's very inability to control the circumstances that prevent oneself from functioning according to prevailing norms may heighten internally felt shame. An individualized sense of powerlessness was a strongly emerging theme in our discussions with individuals living in poverty. Our empirical scholarship provides robust evidence to support the existence of a strong poverty-shame nexus (Chase and Bantebya Kyomuhendo 2015; Gubrium et al. 2014; Walker 2014).

Shame is both an individual and social phenomenon. Our earlier scholarship sought to provide evidence of the debilitating consequences of socially induced shame. Shame was described as co-constructed: it combined "an internal sense of inadequacy" and social shaming, "an imposed or imagined external judgment by others" (Cooley 1922; Goffman 1967, as cited in Chase and Bantebya Kyomuhendo 2015: 3; Mead 1934). The social component included the shame externally imposed on people in poverty through personal dealings with those who were better off, through political and public discourse and through contact with officialdom (Gubrium et al. 2014).

Our evidence showed that negative attitudes and behavior toward people in poverty were pervasive across disparate cultures at different stages of economic development (Chase and Bantebya Kyomuhendo 2015). The evidence also supported the contention that the realm of social policy often reflected negative attitudes.

Figure 1: The Poverty-Shame Nexus

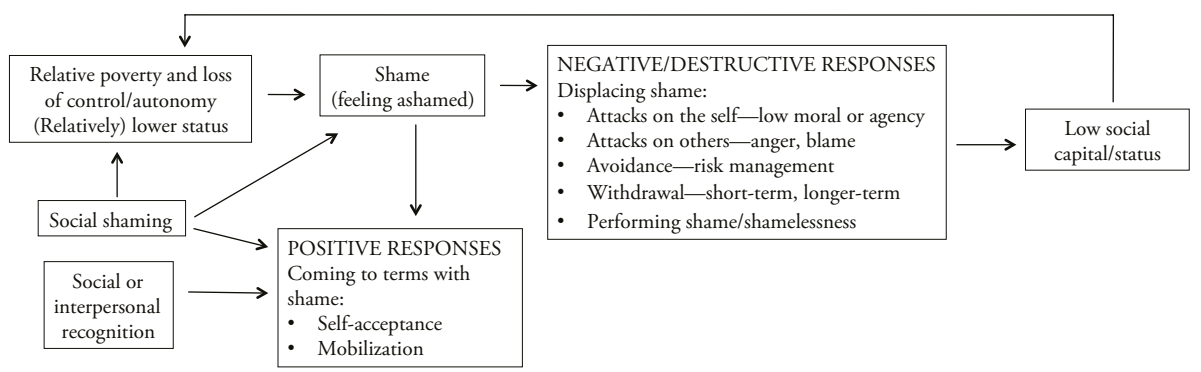

Source: Adapted from Farstad 2016, Lewis 1971, Nathanson 1992 and Walker 2014. 
Interactions during the delivery of antipoverty measures were a primary location in which individuals living in poverty felt humiliated and undermined (Gubrium et al. 2014).

The response to shame for individuals living in poverty was both internalized and externalized (Chase and Bantebya Kyomuhendo 2015; Walker 2014). While shame has been suggested to have a positive role in inducing adaptation to social norms, scant empirical evidence supports this claim (Lewis 1971; Tangney and Dearing 2003). Rather, psychologists have found that shame has a negative emotional impact on individual behavior and actions, as opposed to frequently positive responses to felt guilt. Across our data, we found a strongly emerging pattern of emotions and behaviors described by our respondents, individuals living in poverty. Some found acceptable rationales for their situations and were able to minimize the shame experienced. Some "refused" shame and were deemed "shameless" by their peers and the society around them, supporting the claim by Thomas Scheff (1997) that shame fractures social relationships. Many described the impact of social shaming. They felt categorized unfairly and described the intensely dehumanizing effects of this tendency. The shaming they endured undermined their sense of pride, self-esteem, and dignity (Chase and Bantebya Kyomuhendo 2015; Chase and Walker 2013).

While individuals experiencing shame may have the "positive" potential to acknowledge the shame they experience—and perhaps, to use this position to mobilize themselves to strive toward a higher status, better treatment, or more autonomy-the possibility for mobilization often requires identity-based solidarity (Nathanson 1992; Scheff 2000). Mobilization is not an easy task. Individuals experiencing shame may feel unmotivated and depressed. They may want to distance themselves from others and tend to externalize blame and anger (Tangney et al. 2007). In this sense, shame acts as a "threat to the social bond" (Chase and Walker 2013; Scheff 2000). Negative responses to shame (attacks on the self and on others, social withdrawal) may result in lower social capital, creating a feedback loop in which the cause and effect of shame is further enhanced.

The concept of dignity may serve as a possible antonym for shame. Dignity is positively related to feelings such as integrity, respect, recognition, worth, and status and is negatively related to feelings such as shame, stigma, and lack of recognition (Sayer 2007). While shame is characterized by feelings of inadequacy and lack of worth, to have dignity is to be in control of one self and one's circumstances (Sayer 2007). A feeling of dignity about oneself—self-respect—comes from believing that one is living a life and engaging in activities that are worthwhile (Sayer 2005). One feels shame only if one fails to live in a way valued both by oneself and by society (Sayer 2005). Said another way, dignity is contingent on one's social context: to experience dignity, one must both share a common set of values with one's surrounding society and have or represent the "things that others regard as essential and normal" (Sayer 2007: 569).

This special issue explores how the social relation of poverty and shame or dignity may take place through and within delivery interactions. Our analysis of delivery 
practices enables us to parse out the ways in which policy delivery interactions presumed or enabled individual choice, ability, control, and voice.

\section{Analyzing Delivery Practices}

Public service providers, in interaction with measure recipients, translate policies on the ground into something meaningful (Brodkin and Marston 2013; Lipsky 1980). Providers and recipients experience and understand policy through interaction. Both are mediators of policy. The level of policy mediation afforded each party, however, varies considerably, shaping the elements of discretion, rights, and negotiation across delivery cases. Each of the empirical articles identifies these elements as they occur within the delivery interactions of a particular case, as they connect to heightened shame or enhanced dignity. The three elements of service provision are not succinct categories; there is significant overlap (see Figure 2).

The elements reflect key tensions within the provision of antipoverty measures: Western welfare states have experienced a pendulum swing between rights and discretion over the past several decades (Lødemel and Moreira 2014). Across the Global North and South in recent years, discretion and conditionality have become the new orthodoxy in the provision of welfare benefits and services, with a shift in balance between rights and obligations (Barrientos and Hulme 2008; Surender and Walker 2012). We see this shift most notably in three of our country cases: China, Norway, and the United States.

Figure 2: Analytical Framework

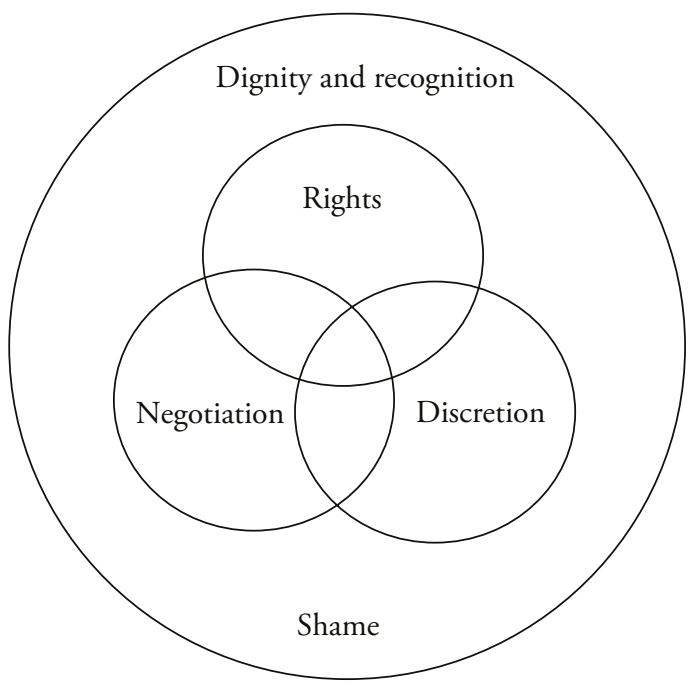


The element of "rights" refers to individual entitlements, typically outweighing what is best for the welfare of all (Dworkin 1978). Rights are "moral constraints on the actions of agents; they constrain the behaviour of individuals who can understand and act for moral reasons" (Quong 2013: 623-624). During delivery encounters, the rights of antipoverty measure recipients may circumscribe how public service providers are authorized to decide and act. Since World War II, Western welfare states have established that citizens have the right to a safety net for those without economic resources or social networks to survive.

Modern social assistance programs within much of the Organisation for Economic Co-operation and Development (OECD) have been funded through national contributions rather than via employment and thus can be said to constitute the lowest threshold of a "right to benefit" for those without another financial or social safety net. Public policy measures imbued with a rights focus may enhance recipient self-worth, social inclusion, and citizenship (Soss 1999), yet they also constrain the actions of those providing such measures.

Rights may be characterized at two levels: in terms of determining eligibility for and accessibility to a benefit or service, or in terms of redressing the failure to provide legally guaranteed benefits or services (De Wispelaere and Morales 2016). For example, within the standard Western antipoverty measure, social assistance, system gatekeepers have long employed a means test to determine eligibility. The test can be more or less invasive and restrictive and, in some cases, can revoke any right to a benefit (Gough et al. 1997).

There is an inherent relationship between rights, which specify the duties of provision for recipients, and discretion, which allows providers "freedom of choice of action" (Hill 2013: 237). An oft-used metaphor to describe this relationship is Ronald Dworkin's "hole of the donut": "the effective decisional room for manoeuvre" (1978: 31) surrounded by a restrictive ring of "context in which rules and regulations exist" (Hupe et al. 2015: 17). Discretion has multiple meanings in the everyday service context. It is necessary to account for and evaluate circumstances if welfare goods and services are to be distributed according to individual need. In the case of most antipoverty measures, rights refer to the distribution of varying welfare benefits and services to those individuals who the provider evaluates as eligible, as these individuals fulfill a prescribed status (Molander et al. 2012). Discretion may also refer to the level of freedom afforded to providers by a particular policy text-the "embedded discretion" that is authorized to professional service providers, allowing them the flexibility to make informed judgments in their work (Brodkin and Marston 2013). This sort of discretion is a "defining characteristic of professionalism" (Lipsky 1980: 215). The more flexible the criteria for eligibility and entitlement are, the more space there is for professional discretion (Molander et al. 2012). We may also refer to "discretion-as-used" (Hupe et al. 2015: 17) and focus on how service providers use or actively claim authorized discretion as they manage their tasks. In these senses, discretion is cast as a positive element, as "reasoned judgments and decisions" necessary 
for the provision of individualized, reflective, and flexible services (Wallander and Molander 2014: 3). Thus, professional discretion speaks to a relationship between recipient and professional (street level bureaucrat) wherein the social worker or service provider "knows best."

Yet discretion may also reflect a threat to rights, when it "threaten(s) the principles of predictability, legality and equal treatment" (Molander et al. 2012). Recipient rights may decrease when discretion is embedded—when delivery roles, resources, and practices are unspecified in policies, guiding documents, or professional employment contracts, leaving them dependent on local contexts, preferences, and power relations. Social norms or moral judgments concerning who is more or less deserving may heavily influence both types of discretion, resulting in sanctions for noncompliance with prescribed norms. In this sense, discretion may reduce services and benefits for recipients and may make provision arbitrary, undermining the notion of rights (Goul Andersen 2012).

The element of "negotiation" links rights and discretion dimensions. Whereas the element of discretion draws attention to the role of service providers in understanding, interpreting, and enacting policy, negotiation involves the interaction between provider and recipient in the mediation of policy. Prevailing social norms and the identities and relative status positions of each party shape the interpersonal negotiations taking place within welfare institutions (Mik-Meyer and Villadsen 2013; Seltzer et al. 2001). Negotiation moves away from a codification of rights-it entails an extension of discretion where, while the recipient is not "the" expert, he or she is "an" expert worth listening to. In a positive sense, negotiation may entail active "bargaining" between service provider and recipient, and it may involve user dialogue, participation, and co-negotiated meaning making about the best shape of services to be provided (Gubrium 2013; Juhila and Abrams 2011).

While negotiation of the terms of one's claim to a benefit may be part of a right, it may also be negative if it represents a move away from a strict rights character and involves an interaction between stakeholders with markedly asymmetrical power relations. The determination of eligibility and entitlement to particular measures may be made in ways that are not socially just or professionally justifiable. Corruption and political patronage may be linked to social protection systems characterized by economic informality, high inequality, and strong ethnic differences. In these cases, eligibility and entitlement may be determined by a recipient being most capable of paying back the provider (e.g., in terms of votes or money), rather than being most in need (Surender and Walker 2012). Rather than the burden of proof falling on the provider or state for failing to provide services (the case with rights-based measures), the need to justify provision is instead circumscribed by the relative status positions of the stakeholders (including the state, the street level bureaucrat, the recipient). In cases characterized by corruption, patronage, or clientelism, negotiation may even more deeply reinscribe existing power relations (Pellissery 2006). In these cases, eligibility 
and access to services may depend on the networks and contacts possessed by the user, superseding the aim to adhere to professional and institutional norms or judgments.

Both discretion and negotiation may negatively impinge on the rights of recipients, if providers make decisions with little or no justification, reflecting a grossly unequal power dynamic. In these cases, accountability—the "obligation to justify" — may help to alleviate this problem, thus ensuring that reasonable and justifiable decisions take place (Molander et al. 2012: 215). The presence of clear rules for measure entitlement also minimizes discretion, but this may conflict with the ability of providers to offer individualized treatment to recipients (Molander et al 2012). Where there is little expectation of accountability (because of corruption, power dynamics, or low recipient status), we may expect that recipient rights will be diminished, and this may enhance the sense of shame experienced.

\section{Shaming and Dignity Building across Five Delivery Cases}

The five empirical articles that follow highlight the role that rights, discretion, and negotiation play in the psychosocial impact that delivery interactions have on measure recipients. We provide below a brief introduction to each of the articles, followed by an overview of relevant themes emerging across the five studies.

In China, Jian Chen and Lichao Yang describe how the idea and practice of rights, discretion, and negotiation surrounding the provision of dibao (minimum income benefits) differed between urban and rural settings. A tradition for family-based welfare and a lack of emphasis on individual rights have limited the rights-based thinking of claimants, although this has changed in recent years. In the urban context, eligibility rights reflect a bureaucratic notion of documentation and poverty thresholds, with little room for service providers to acknowledge the varying circumstances of claimants when making decisions on eligibility. The limited ability of claimants to negotiate their eligibility is in part intended to combat would-be "speculators" attempting to claim the benefit. Yet low negotiation also constrains the rights of the most vulnerable claimants, many of whom lack the proper documentation to establish eligibility. Claimant rights are further limited in the urban setting because of the lack of public awareness of eligibility for the benefit itself. In rural areas, the realized rights of claimants are heavily shaped by social customs, by local power structures, and by professional discretion concerning deservingness. Increased professional and local discretion has both positive and negative impacts on the claimant. Given the increased space for discretion in the rural setting, the authors suggest that interactions between service providers and claimants often help to ensure the rights of most needy dibao claimants, even as high status claimants may also be able to negotiate with local committees to attain benefits. The possibility for negotiation according to individual circumstances enables a higher sense of dignity for those with dibao status in the rural setting. 
In India, Sony Pellissery, Sattwick Dey Biswas, and Biju Abraham describe how corruption and personal discretion have pervaded the provision of midday meals for grade school students. While policy texts adhere to a heavy rights mantra, in practice, rights are constrained through the local discretion of service providers, many of whom are caught in a system of graft and corruption. While local advisory groups are, on paper, a place for exercising negotiation power, the potential to realize rights through this means is undermined by the inability of most vulnerable families to participate. Rights are further limited by the stigmatized nature of the measure. Families with more resources opt out of this poorly resourced and serviced "food for the poor" program. The possibility for rights and negotiation for those most vulnerable is undermined by lack of resources invested, as well as by any recognized agency to effectively mobilize. Thus, the potential for negotiation is undermined by reinforced power domains, as those students who continue to avail themselves of the midday meals have no other choice, and this situation creates shame.

In Norway, Erika Gubrium, Leah Johnstone, and Ivar Lødemel suggest that the rights of participants engaged in a national labor activation program are predicated on their ability to follow an institutionally specified activation trajectory. The realization of meaningful rights is heavily shaped by the labor market, yet the policy design and resources specified for the program only acknowledge the institutional interactions between the caseworker and the recipient. Professional discretion and interactional negotiation are constrained by an emphasis on the individual will of participants and their motivation to find work. The focus on capability over need has resulted in a system in which those with more resources tend to attain more and may gain dignity through work found through the program. This reflects a changed conception of rights, from a distributive, needs-based ethos to a focus on parsing out the best "investment." For those unable to move forward into work, an incompatibility between the strong institutional emphasis on individuals to "improve the self" versus the reality of a difficult labor market both heightens shame for those who cannot find work and limits the space for challenging the shame experienced.

In Uganda, Grace Bantebya Kyomuhendo reports on an "absence of rights" for recipients of a senior citizens grant due to a lack of clear instruction from the state to local providers about entitlement rules. Officials have delegated servicing responsibilities to the local community yet have failed to specify the terms of eligibility for the grant (to be awarded to all individuals over sixty-five years old). This strategy enables officials to avoid blame and gain political support. Misinformed local providers engage in shaming toward recipients, whose imagined deservingness is low. Recipient rights are also limited by severely low benefit levels, which shames both those better off and the elderly individuals categorized as "poor." Lacking clear eligibility criteria, local service providers instead use neighborhood discretion to determine eligibility. The personally and locally invasive and physically rigorous process for maintaining eligibility reproduces prevailing power relations. The opportunity cost of claiming benefits for those with lower social status is high. Shame is experienced by the most 
vulnerable because of the design of the benefit itself and to the process for attaining the benefit. Only the truly desperate continue to endure the difficult process of claiming this "universal" benefit.

In the United States, Erika Gubrium, Laura Sylvester, Sabina Dhakal, and Aline Gubrium describe a case in which most remaining means-tested benefits are now managed at the state/local level and political priorities have left few resources for antipoverty measures. In focus are public housing sites, which are marked by heavy social and institutional assumptions concerning individual "choice" and individualized blame for residents' difficult circumstances. Rhetorically, the policy focus is for residents to "pull themselves up by their bootstraps" to take control of their lives, but difficult system logistics make the project of seeking autonomy a difficult one. Housing benefits and the determination of eligibility for residency are shaped and delivered in a discretionary way, with the use of heavy bureaucratic requirements for selection against those who can "choose" better. With this, the implicit aim of case reduction has been fulfilled. The dissonance between the rhetoric of "choice" and an untenable welfare system serve to enhance the sense of shame and powerlessness of residents, resulting in what may be a negative feedback loop for many of the most vulnerable.

\section{Social Citizenship to Transform Delivery Interactions}

In this final section, we aim to theorize, based on the empirical findings reported in this special issue, how social citizenship has the potential to structure the relationships between welfare recipients and administrators in the framework of rights, discretion, and negotiations. As a concept, social citizenship transcends legalistic connotations and transforms the sites of welfare delivery into spaces of dialogue and social struggle (Fraser 2010; Nedelsky and Scott 1992).

Many of the differences reported in this special issue between US and Norwegian cases have been explained through differences in arrangements or welfare state organization (Esping-Andersen 1990; Hall and Soskice 2003). The cases of China, India, and Uganda do not fit into these classifications, but viewed through the lens of realization of human dignity for welfare recipients, we trace a pattern wherein social class defines the citizenship entitlements (Marshall 1950) in all five countries. It is here where the distinction of two types of justice that Amartya Sen (2009) has demonstrated in his work on The Idea of Justice - "realization focused" and "arrangement focused"become relevant.

The organizational arrangements to deliver welfare services form a bureaucracy of their own. In all case countries, service delivery was heavily managed by experts who held different views on rights than did the recipients. Very often, this interpretation of rights was hugely different from what was intended in the legislation. Politics of needs as interpreted by experts (Arendt 1958) tends to reflect the concerns of the institutions rather than individuals. In this sense, an administrative view of social policy dominates 
the political view of social policy (Kaufmann 2012) and emphasizes "rightness" while interpreting rights. The discourse distinguishing between "deserving" and "undeserving" comes from the "arrangement focused" justice of administrative wisdom.

A political view of social policy emphasizes human freedom rather than "rightness" (Arendt 1958). The weight accorded to human freedom within the provision of welfare state organizational arrangement is hugely different between the contexts of the Global South and the Global North. In the case of Norway, we find spaces of negotiation between the recipients and the service providers in efforts to find meaningful work. In the case of the United States, the service providers attributed the space for negotiation to the rule-abiding behavior of the residents in public housing. Compared to these, in India, China, and Uganda, recipients lost negotiating space because they were recipients. In other words, the "equal moral worth of human beings" (Fraser and Honneth 2003: 229) that ensures parity of participation was absent. When the power distance between the recipient and the policymaker is very high, the possibility to realize human freedom, and thus dignity, shrinks (Pellissery 2015). Social accountability initiatives in the Global South (Grandvoinnet et al. 2015) aim to bridge the power imbalance in the state-citizen interface through transparency norms. Without such transparency measures, the dignity to be accorded to service recipients is shrouded under a veil of social/local norms, as reported in the case studies in this issue. Such an action by state officials will create Marshallian (1950), class-specific citizenship. However, post-Marshallian citizenship "centres on negotiation around human needs and social rights, which is not necessarily subservient to frameworks for constitutional civil and political order" (Dean 2013: 40).

International political discourse on social rights along the lines of human rights has the potential to radicalize the notions of social citizenship in present times (Davy et al. 2013). Social citizenship as a concept is expanding the objects of social rights beyond materiality of human life (e.g. housing, pensions). Intangible processual elements are being included as the construct of rights. Dignified treatment in the bureaucratic interactions is one such processual element. Experiments in the Global South, through "social audits" and "right to service," are expressions of the voice of citizens to claim the space that was hitherto denied by the experts. The claim for dignified treatment in the citizen-state interface would soon be a reality if dignity were recognized a social right.

\section{Acknowledgments}

The data on which this article is based was gathered as part of the Norwegian Research Council, Welfare, Work and Migration project number 225126, "Poverty and Shame: Perspectives and Practices Concerning Anti-poverty Measures." The funded project is attached to the research group Society, Welfare, and Policy and to the Competence Centre on Work Inclusion, both at the Oslo and Akershus University College, in Oslo, Norway. 
Erika Gubrium is an associate professor at the Faculty of Social Sciences at Oslo and Akershus University College. She uses comparative, qualitative methodologies to study the interactional dynamics between sociocultural norms, policy measure intentions, and system ethos. Her work has in recent years focused on measures attached to labor activation within Norway and internationally.

Sony Pellissery is an Associate Professor at the Centre for the Study of Social Exclusion and Inclusive Policy at National Law School University in Bangalore, India. He focuses on the delivery of antipoverty measures in rural and urban India. He is a leading national scholar on poverty-related research and comparative perspectives in policy theory. He was awarded the Ram Reddy Memorial Social Scientist Award in 2015.

\section{References}

Arendt, H. 1958. The Human Condition. Chicago: University of Chicago Press.

Bantebya Kyomuhendo, G. 2014. “'Food That Cannot Be Eaten': The Shame of Uganda's AntiPoverty Policies." In Gubrium et al. 2014, 157-178.

Barrientos, A., and D. Hulme. 2008. Social Protection for the Poor and Poorest: Concepts, Policies and Politics. Basingstoke: Palgrave Macmillan.

Baumberg, B., K. Bell, and D. Gaffney, with R. Deacon, C. Hood, and D. Sage. 2012. Benefits Stigma in Britain. London: Elizabeth Finn Care/Turn2us.

Betcherman, G., K. Olivas, and A. Dar. 2004. Impacts of Active Labour Market Programmes: New Evidence from Evaluations with Particular Attention to Developing and Transition Countries. Social Protection Discussion Paper Series No. 0402. Washington, DC: World Bank.

Borghi, V., and R. van Berkel. 2007. "Individualised Service Provision in an Era of Activation and New Governance." International Journal of Sociology and Social Policy 27 (9-10): 413-424.

Brodkin, E.Z., and G. Marston, eds. 2013. Work and the Welfare State: Street-Level Organizations and Workfare Politics. Washington, DC: Georgetown University Press.

Caswell, D., L. Eskelinen, and S.-P. Olesen. 2011. "Identity Work and Client Resistance underneath the Canopy of Active Employment Policy." Qualitative Social Work 1 (1): 1-16.

Chase, E., and G. Bantebya Kyomuhendo, eds. 2015. Poverty and Shame: Global Experiences. Oxford: Oxford University Press.

Chase, E., and R. Walker. 2013. "The Co-construction of Shame in the Context of Poverty: Beyond a Threat to the Social Bond." Sociology 47 (4): 739-754.

Chen, V.T. 2015. Cut Loose: Jobless and Hopeless in an Unfair Economy. Berkeley: University of California Press.

Cooley, C.H. 1922. Human Nature and the Social Order. New York: Scribner's.

Davy, B., U. Davy, and L. Leisering. 2013. "The Global, the Social and Rights: New Perspectives on Social Citizenship.” International Journal of Social Welfare 22 (1): 1-14.

Dean, H. 2013. "The Translation of Needs into Rights: Reconceptualising Social Citizenship as a Global Phenomenon.” International Journal of Social Welfare 22 (1): 32-49. 
De Wispelaere, J., and L. Morales. 2016. "Is There (or Should There Be) a Right to Basic Income?" Philosophy and Social Criticism 42 (9): 920-936. doi:10.1177/0191453715625439.

Dovidio, J.F., B. Major, and J. Crocker. 2000. "Stigma: Introduction and Overview." In The Social Psychology of Stigma, ed. T.F. Heatherton, R.E. Kleck, M.R. Hebl, and J.G. Hull, 1-28. New York: Guilford Press.

Dworkin, R. 1978. Taking Rights Seriously. Cambridge, MA: Harvard University Press.

Esping-Andersen, G. 1990. Three Worlds of Welfare Capitalism. Princeton, NJ: Princeton University Press.

Fraser, N. 2010. Scales of Justice: Reimagining Political Space in a Globalizing World. New York: Columbia University Press.

Fraser, N., and A. Honneth. 2003. Redistribution or Recognition? A Political-Philosophical Exchange. London: Verso.

Goffman, I. 1963. Stigma: Notes on the Management of Spoiled Identity. Englewood Cliffs, NJ: Prentice-Hall.

Goffman, I. 1967. Interaction Ritual: Essays on Face-to-Face Behavior. New York: Anchor.

Gough, I., J. Bradshaw, J. Ditch, T. Eardley, and P. Whiteford. 1997. "Social Assistance in OECD Countries." Journal of European Social Policy 7 (1): 17-43.

Goul Andersen, J. 2012. The Concept of Universalism and Its Operationalisation in a Mixed Economy of Welfare. CCWS Working Paper No. 81. Aalborg: Aalborg University Centre for Comparative Welfare Studies.

Grandvoinnet, H., G. Aslam, and S. Raha. 2015. Opening the Blackbox: The Contextual Drivers of Social Accountability. Washington, DC: World Bank.

Gubrium, E.K. 2013. "Participant Meaning-Making along the Work Trajectory of a Labour Activation Programme." In Turning Troubles into Problems: Clientization in Human Services, ed. J.F. Gubrium and M. Järvinen, 137-154. London: Routledge.

Gubrium, E.K., S. Pellissery, and I. Lødemel, eds. 2014. The Shame of It: Global Perspectives on AntiPoverty Policies. Bristol: Policy Press.

Gubrium, E.K., B. Leibetseder, D. Dierckx, and P. Raeymaeckers. Forthcoming. "Investing in Work: A Multi-level Assessment of Intensified Social Assistance Landscapes in Austria, Belgium and Norway." International Journal of Sociology and Social Policy 37 (9-10).

Hall, C., K. Juhila, N. Parton, and T. Pösö, eds. 2003. Constructing Clienthood in Social Work and Human Practices: Interaction, Identities and Practices. London: Jessica Kingsley Publishers.

Hall, P.A., and D. Soskice. 2003. Varieties of Capitalism: The Institutional Foundations of Comparative Advantage. Oxford: Oxford University Press.

Hickey, S. 2011. Beyond the Poverty Agenda? Insights from the New Politics of Development in Uganda. Working Paper No. 221. Manchester: Chronic Poverty Research Centre.

Hill, M. 2013. The Public Policy Process. Harlow: Pearson.

Hupe, P., M. Hill, and A. Buffat. 2015. Understanding Street-Level Bureaucracy. Bristol: Policy Press. Jewell, C. 2007. Agents of the Welfare State: How Caseworkers Respond to Need in the United States, Germany and Sweden. New York: Palgrave Macmillan.

Juhila, K., and L.S. Abrams. 2011. "Special Issue Editorial: Constructing Identities in Social Work Settings." Qualitative Social Work 10 (3): 277-292.

Kaufmann, F. 2012. European Foundations of the Welfare State. New York: Berghahn Books. 
Kluve, J. 2006. The Effectiveness of European Active Labor Market Policy. RWI Discussion Paper No. 37. Essen: Ruhr Economic Papers. https://papers.ssrn.com/sol3/papers.cfm?abstract_ id $=892341$.

Larsen, C.A. 2006. The Institutional Logic of Welfare Attitudes: How Welfare Regimes Influence Public Support. Hampshire: Ashgate.

Lewis, H.B. 1971. Shame and Guilt in Neurosis. New York: International Universities Press.

Lipsky, M. 1980. Street Level Bureaucracy: Dilemmas of the Individual in Public Services. New York: Russell Sage Foundation.

Lister, R. 2004. Poverty. Cambridge: Polity.

Lødemel, I., and A. Moreira, eds. 2014. Activation or Workfare? Governance and the Neo-Liberal Convergence. New York: Oxford University Press.

Malmberg-Heimonen, I., and J. Vuori. 2005. "Financial Incentives and Job-Search Training: Methods to Increase Labour Market Integration in Contemporary Welfare States?” Social Policy \& Administration 39 (3): 247-259.

Marshall, T.H. 1950. Citizenship and Social Class and other Essays. Cambridge: Cambridge University Press.

Mead, G.H. 1934. Mind, Self and Society. Chicago: University of Chicago Press.

Mik-Meyer, N. and K. Villadsen. 2013. Power and Welfare: Understanding Citizens' Encounters with State Welfare. London: Routledge.

Molander, A., H. Grimen, and E.O. Eriksen. 2012, "Professional Discretion and Accountability in the Welfare State." Journal of Applied Philosophy 29 (3): 214-230.

Narayan, D., R. Chambers, M. Shah, and P. Petesch. 2000. Voices of the Poor: Crying Out for Change. New York: Oxford University Press.

Nathanson, D. 1992. Shame and Pride: Affect, Sex and the Birth of the Self. New York: Norton.

Nedelsky, J., and C. Scott. 1992. "Constitutional Dialogue." In Social Justice and the Constitution: Perspectives on a Social Union for Canada, ed. J. Bakan and D. Schneiderman, 59-84. Ottawa: Carleton University Press.

Olesen, S.-P., and L. Eskelinen. 2011. "Short Narratives as a Qualitative Approach to Effects of Social Work Interventions." Nordic Social Work Research 1 (1): 61-77.

Pellissery, S. 2006. Do Public Works Programmes Ensure Employment in the Rural Informal Sector? Examining the Employment Guarantee Scheme in Rural Maharashtra, India. Barnett Papers in Social Research. Oxford: University of Oxford.

Pellissery, S. 2015. "Public Policy and Moral Worthiness of Citizens." Lecture presented at the Prof. G. Ram Reddy Social Scientist Award Lecture, Hyderabad, 4 December.

Pinker, R. 1971. Social Theory and Social Policy. London: Heinenmann Educational Books.

Quong, J. 2013. "Rights." In The Routledge Companion to Social and Political Philosophy, ed. G. Gaus and F. D'Agostino, 618-628. London: Routledge.

Robeyns, I. 2005. "The Capability Approach: A Theoretical Survey." Journal of Human Development 6 (1): 93-114.

Rønsen, M., and T. Skarðhamar. 2009. "Do Welfare-to-Work Initiatives Work? Evidence from an Activation Programme Targeted at Social Assistance Recipients in Norway." Journal of European Social Policy 19 (1): 61-77.

Sayer, A.R. 2005. "Class, Worth and Recognition." Sociology 39 (5): 947-963.

Sayer, A.R. 2007. "Dignity at Work: Broadening the Agenda." Organization 14 (4): 565-581. 
Schafft, A., and Ø. Spjelkavik. 2011. "Kvalifiseringsprogrammet: Sosialklientenes vei til arbeidslivet [The Qualification Program: The social assistance client's way to worklife]." In NAV ved et Veiskille: Organisasjonsendring som Velferdsreform [NAV at a crossroads: Organizational change as welfare reform], ed. T. Andreassen and K. Fossestøl, 127-146. Oslo: Gyldendal Akademisk.

Scheff, T.J. 1997. Emotions, the Social Bond, and Human Reality: Part/Whole Analysis. New York: Cambridge University Press.

Scheff, T.J. 2000. "Shame and the Social Bond: A Sociological Theory." Sociological Theory 18 (1): 84-98.

Seltzer, M., C. Kullberg, S.P. Olesen, and I. Rostila, eds. 2001. Listening to the Welfare State. Aldershot: Ashgate.

Sen, A. 1983. "Poor, Relatively Speaking." Oxford Economic Papers 35: 153-169.

Sen, A. 1999. Commodities and Capabilities. Delhi: Oxford University Press.

Sen, A. 2005. "Human Rights and Capabilities." Journal of Human Development 6 (2): 151-166.

Sen, A. 2009. The Idea of Justice. London: Allen Lane.

Soss, J. 1999. "Lessons of Welfare: Policy Design, Political Learning, and Political Action." American Political Science Review 93 (2): 363-380.

Spicker, P. 1984. Stigma and Social Welfare. London: Croom Helm.

Surender, R., and R. Walker, eds. 2012. Social Policy in a Developing World. Cheltenham: Edward Elgar.

Tangney, J., and R.L. Dearing. 2003. Shame and Guilt: Masters of Disguise. New York: Guilford Press.

Townsend, P. 1979. Poverty in the United Kingdom. Harmondsworth: Penguin.

Turner, J.H., and A. Maryanski. 2013. "The Evolution of the Neurological Basis for Sociality." In Handbook of Neurosociology, ed. D.D. Franks, 289-309. New York: Springer.

United Nations Development Programme (UNDP). 2003. Poverty Reduction and Human Rights: A Practice Note. New York: UNDP.

United Nations Sustainable Development (UNSD). 2017. “Goals.” http://www.un.org/ sustainabledevelopment/poverty (accessed 24 April).

van Berkel, R., and B. Valkenburg. 2007. Making It Personal: Individualising Activation Services in the EU. Bristol: Policy Press.

Walker, R. 2014. The Shame of Poverty. Oxford: Oxford University Press.

Wallander, L., and A. Molander. 2014. "Disentangling Professional Discretion: A Conceptual and Methodological Approach." Professions \& Professionalism 4 (3): 1-19. 